\title{
Nodulation of Aeschynomene afraspera and A. indica by Photosynthetic Bradyrhizobium Sp. Strain ORS285: The Nod-Dependent Versus the Nod-Independent Symbiotic Interaction
}

\author{
Katia Bonaldi, ${ }^{1,2}$ Daniel Gargani, ${ }^{3}$ Yves Prin, ${ }^{4}$ Joel Fardoux, ${ }^{1}$ Djamel Gully, ${ }^{1}$ Nico Nouwen, ${ }^{1}$ \\ Sofie Goormachtig, ${ }^{5,6}$ and Eric Giraud ${ }^{1}$ \\ ${ }^{1}$ IRD, Laboratoire des Symbioses Tropicales et Méditerranéennes (LSTM), UMR IRD/SupAgro/INRA/UM2/CIRAD, F-34398 \\ Montpellier, France; ${ }^{2}$ UM2, F-34095 Montpellier, France; ${ }^{3} \mathrm{CIRAD}$, UMR BGPI INRA/CIRAD/SUP AGRO, Campus International \\ de Baillarguet, 34398 Montpellier cedex 5, France; ${ }^{4}$ CIRAD, LSTM, UMR IRD/SupAgro/INRA/UM2/CIRAD, F-34398 \\ Montpellier, France; ${ }^{5}$ Department of Plant Systems Biology, VIB, and ${ }^{6}$ Department of Plant Biotechnology and Genetics, \\ Ghent University, Technologiepark 927, B-9052 Gent, Belgium
}

Submitted 13 April 2011. Accepted 10 May 2011.

\begin{abstract}
Here, we present a comparative analysis of the nodulation processes of Aeschynomene afraspera and $A$. indica that differ in their requirement for Nod factors (NF) to initiate symbiosis with photosynthetic bradyrhizobia. The infection process and nodule organogenesis was examined using the green fluorescent protein-labeled Bradyrhizobium sp. strain ORS285 able to nodulate both species. In $A$. indica, when the NF-independent strategy is used, bacteria penetrated the root intercellularly between axillary root hairs and invaded the subepidermal cortical cells by invagination of the host cell wall. Whereas the first infected cortical cells collapsed, the infected ones immediately beneath kept their integrity and divided repeatedly to form the nodule. In $A$. afraspera, when the NF-dependent strategy is used, bacteria entered the plant through epidermal fissures generated by the emergence of lateral roots and spread deeper intercellularly in the root cortex, infecting some cortical cells during their progression. Whereas the infected cells of the lower cortical layers divided rapidly to form the nodule, the infected cells of the upper layers gave rise to an outgrowth in which the bacteria remained enclosed in large tubular structures. Together, two distinct modes of infection and nodule organogenesis coexist in Aeschynomene legumes, each displaying original features.
\end{abstract}

The infection of legume plants by Rhizobium spp. leads to the formation of root organs, the nodules, in which the bacteria fix atmospheric dinitrogen to the benefit of the plant. Some Aeschynomene spp. belonging to the Dalbergioid clade, a pantropical large group of papilionoid legumes, display the very unusual property of forming nitrogen-fixing nodules on both the root and stem (Boivin et al. 1997). This stem nodulation can be very profuse, as observed for Aeschynomene afraspera and A. nilotica, resulting in a very high

Corresponding author: E. Giraud; Telephone: 33 467593783, Fax: 33 467593802; E-mail: eric.giraud@ird.fr

* The $\boldsymbol{e}$-Xtra logo stands for "electronic extra" and indicates that three supplementary figures are published online and that Figures 1 through 8 appear in color online. nitrogen fixation rate, rendering these plants ideal as "green manure" for rice production (Alazard and Becker 1987). Another unusual feature of these Aeschynomene spp. is their capacity to be symbiotically associated with specific rhizobia from the genus Bradyrhizobium, which are photosynthetic (Eaglesham et al. 1990, Giraud and Fleischman 2004). The most unexpected and unique feature of this symbiosis is that some photosynthetic bradyrhizobia (ORS278 and BTAi1 strains) lack the canonical $\operatorname{nod} A B C$ genes required for the synthesis of Nod factors (NF), the lipochitooligosaccharide signal molecules produced by all other rhizobia that had always been suggested as compulsory to initiate symbiosis (Giraud et al. 2007). Hence, some photosynthetic Bradyrhizobium strains use an alternative pathway, thus far unknown, other than the one mediated via NF to initiate symbioses with Aeschynomene plants.

The absence of nod genes is not the general rule among photosynthetic bradyrhizobia. Some strains, such as the model strain ORS285, do contain nodABC genes but only use NF to infect specific Aeschynomene spp. (Chaintreuil et al. 2001). Indeed, it has been shown that the nod genes of ORS285 are absolutely required to initiate symbiosis with some species such as $A$. afraspera whereas they were dispensable for the symbiosis with A. indica or A. sensitiva that are also nodulated by the nod gene lacking BTAi1 and ORS278 strains (Giraud et al. 2007). Thus, in summary, two types of interactions can be distinguished in Aeschynomene-photosynthetic Bradyrhizobium symbioses-a classical one which is NF dependent and an atypical one which is NF independent-and it is the Aeschynomene sp. that determines the signaling modus. Likewise, the nod-containing photosynthetic strains such as ORS285 are able to use both strategies depending on the host plant.

Nodulation consists of two main developmental pathways, bacterial infection and organ formation, and the two processes merge when the bacteria are taken up by the plant cells and develop into bacteroids to fix nitrogen. Although NF constitute the "sesame" that permits most rhizobia to open the legume door, different modes of bacterial invasion have been described. The best known, encountered in most of the temperate legumes examined thus far, involves primary entry of bacteria into deformed root hairs through infection threads 
(IT) (Gage 2004; Gibson et al. 2008). Concomitantly with root hair infection, NF induce mitotic reactivation of cortical cells to form a nodule primordium. Then, the IT penetrate the underlying root cortex to reach the nodule primordium where bacteria are released inside the plant cytoplasm. However, in many tropical or subtropical legumes, bacteria enter via epidermal fissures (cracks) generated by the emergence of lateral roots, a process called "crack entry" (Boogerd and van Rossum 1997; Sprent 1989). The mechanism for deeper invasion varies depending on the legume species. In Sesbania rostrata and Neptunia natans, the invasion involves the formation of intercellular infection pockets and the subsequent formation of IT that spread toward the meristematic zone (Capoen et al. 2010; Ndoye et al. 1994; Subba-Rao et al.
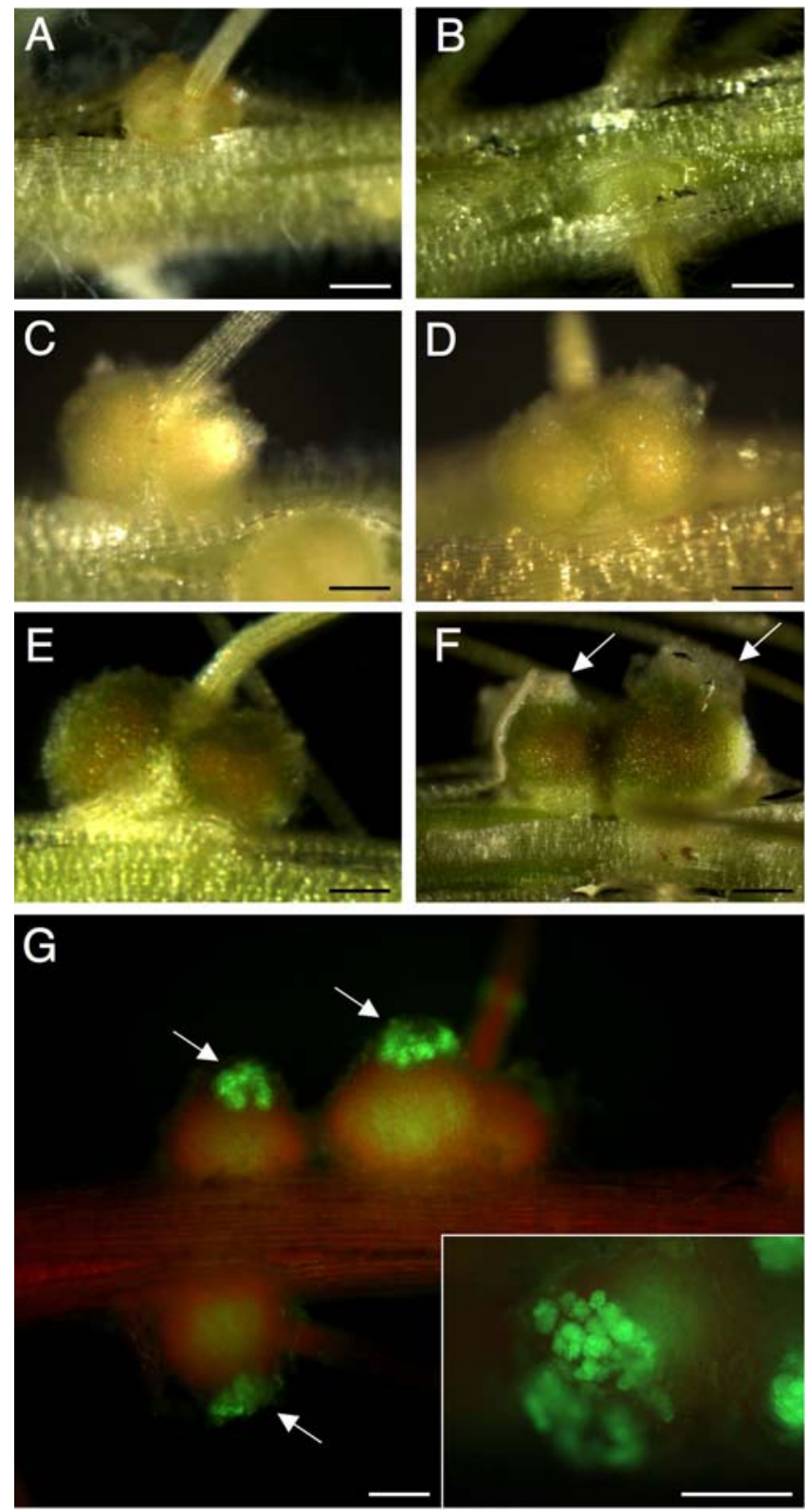

Fig. 1. Root nodule development of A, C, and E, Aeschynomene indica; and B, D, and F, A. afraspera inoculated by ORS285 $\Delta$ nodB and ORS285, respectively. A and B, Emerging nodules at 3 days postinoculation (dpi). $\mathbf{C}$ and D, Young nodules at $5 \mathrm{dpi}$. E and F, Mature nodules at $10 \mathrm{dpi}$. G, $A$. afraspera mature nodules as observed with a fluorescent stereomicroscope equipped with fluorescein isothiocyanate filter. Note that the outgrowths are infected by green fluorescent protein bacteria (white arrows). Inset: higher magnification of the outgrowth. Bar, $500 \mu \mathrm{m}$.
1995). In Stylosanthes spp., infection progresses in the root cortex by progressive collapses of infected cells whereas, in Arachis hypogea, bacteria spread intercellularly through the middle lamellae (Chandler 1978; Chandler et al. 1982). In the last two cases, neither the formation of IT nor the distant induction of a primordium were observed. The intercellular bacteria directly invade some cortical cells via an endocytosislike process, and only after this step do the newly infected cortical cells start to divide repeatedly, giving rise to the typical aeschynomenoid nodule where the core-infected zone is not interspersed with uninfected cells (Lavin et al. 2001).

Most of the studies in Aeschynomene spp. have dealt with the ultrastructure of established root and stem nodules (Alazard and Duhoux 1988, 1990; Arora 1954; Loureiro et al. 1995; Vaughn and Elmore 1985; Yatazawa et al. 1984). Whatever the species studied, nodules were always found at the emergence of lateral roots, suggesting that the nod-lacking and the nod-containing photosynthetic Bradyrhizobium strains infect the plant via a crack-entry process. However, the precise invasion mode during the NF-independent symbiosis was not yet studied. As a result, it is currently unknown whether the mechanism of deeper invasion differs between the two types of bacteria whereas fundamental differences could be expected, considering the key roles played by NF during the different steps of the infection process in conventional legumes.

The aim of this work was to compare the nodulation processes of two Aeschynomene spp. that differ in their requirement of NF to initiate symbiosis. We characterized the early events of infection and nodule organogenesis of Aeschynomene afraspera and A. indica inoculated with the photosynthetic Bradyrhizobium sp. ORS285, a strain that is able to symbiotically interact with both species using a NF-dependent and NF-independent process, respectively.

\section{RESULTS}

\section{Comparison of the symbiotic efficiency of $A$. indica and $A$. afraspera.}

To compare the efficiency of the NF-dependent and NFindependent symbiotic processes, we took advantage of the ability of the ORS285 strain to nodulate both A. indica and $A$. afraspera. In the case of $A$. indica nodulation, the ORS285 $\triangle$ nodB strain carrying a deletion in the NF biosynthesis $\operatorname{nod} B$ gene was used to exclude possible NF effects. Both ORS285 and ORS285 $\Delta$ nodB strains contained a stable plasmid constitutively expressing green fluorescent protein (GFP). Note that no differences in the infection process and the course of nodule development were observed in A. indica inoculated with either the wild-type strain ORS278 or the mutant strain $285 \Delta \operatorname{nodB}$ (data not shown).

The kinetics of nodule development were similar in both plant species (Fig. 1; Supplementary Fig. S1). At 3 days postinoculation (dpi), bumps were seen at the lateral root bases (Fig. 1A and B). Two days later, at $5 \mathrm{dpi}$, the nodules clearly emerged and displayed their classical spherical shape (Fig. 1C and D). At 7 to $10 \mathrm{dpi}$, the nodules reached their mature size (Fig. 1E and F). Whereas mature $A$. indica nodules were perfectly spherical, A. afraspera nodules displayed an outgrowth at the top of the nodules (Fig. 1F). Fluorescence stereomicroscopy showed that this outgrowth was infected by GFP-tagged bacteria (Fig. 1G). At $7 \mathrm{dpi}$, the average number of nodules per plant was comparable between the two species (14 \pm 3 for $A$. indica and $10 \pm 4$ for $A$. afraspera). This number increased after 3 weeks ( $21 \pm 4$ for $A$. indica and $15 \pm 3$ for A. afraspera). It is worth noting that nitrogen fixation, measured by the acetylene reduction assay (ARA), could be detected as early as 5 dpi for both species. The ARA activity 
drastically increased from 5 to $7 \mathrm{dpi}$ and $\mathrm{C}_{2} \mathrm{H}_{4}$ reached 0.36 $\mu$ mol plant ${ }^{-1} \mathrm{~h}^{-1}$ for A. indica and $0.64 \mu \mathrm{mol}$ plant $^{-1} \mathrm{~h}^{-1}$ for $A$. afraspera.

To compare the infectiveness of ORS285 and ORS285$\triangle \operatorname{nodB}$, serial dilutions of fresh cultures were inoculated on $A$. afraspera and $A$. indica, respectively. The total number of nodules formed on five plants was counted after 10 days. In both cases, no significant difference was observed for inoculum density varying from $10^{7}$ to $10^{1}$ bacteria. $\mathrm{ml}^{-1}$. This indicated that the bacteria were able to induce nodules at a very low cell density whatever the symbiotic strategy used.
Altogether, these data clearly show that the NF-independent symbiosis ( $A$. indica-ORS285 $\Delta$ nodB) was established as efficiently as the NF-dependent one (A. afraspera-ORS285).

\section{Root infection.}

The early steps of the infection process of both Aeschynomene spp. were monitored by confocal microscopy, light microscopy, and electron microscopy.

The first event observed in A. indica was an intensive proliferation of bacteria at the surface of the axillary root hairs surrounding lateral root bases (Fig. 2A and $\mathrm{C}$ ). These axillary
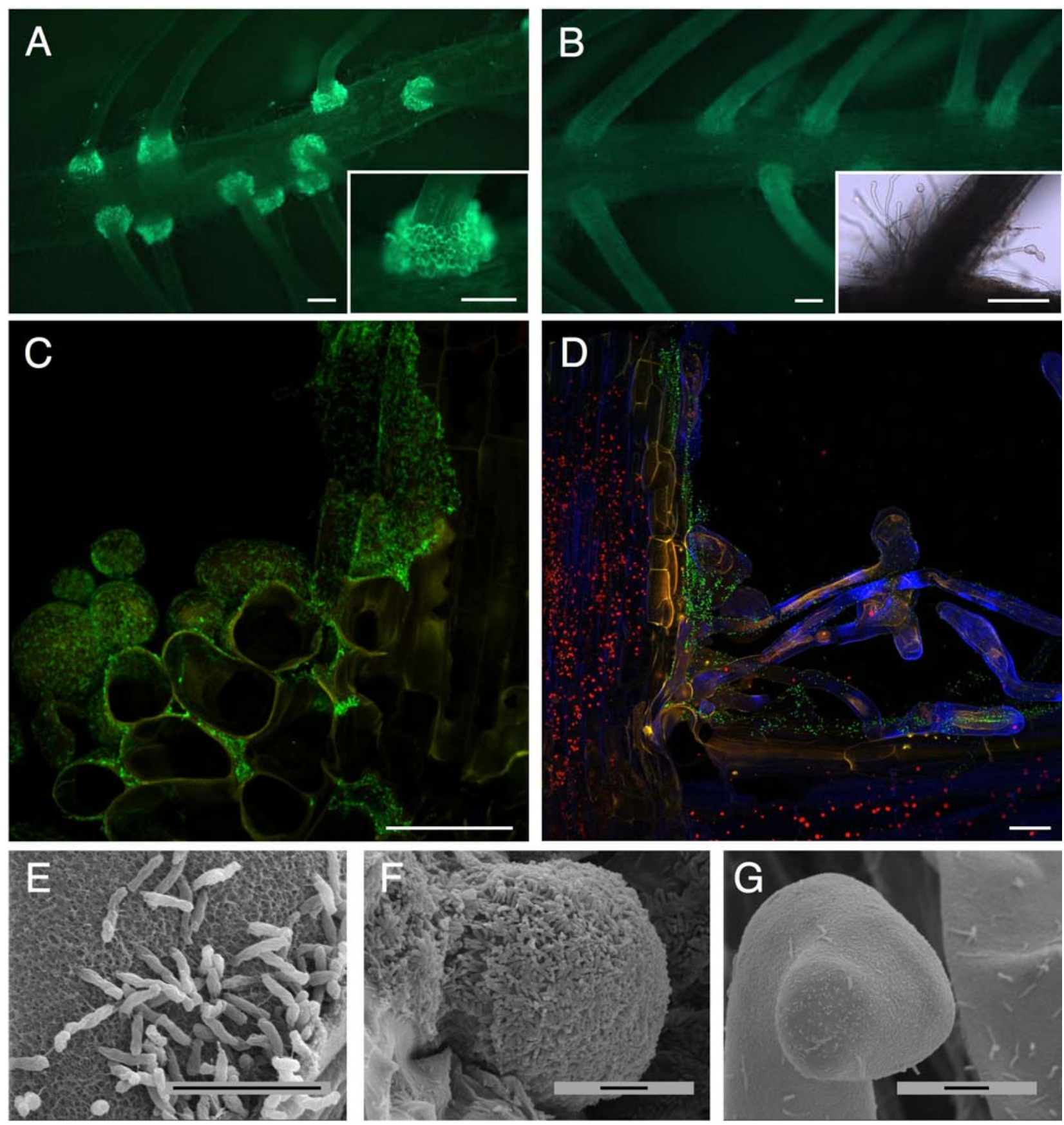

Fig. 2. Comparison of root bacterial colonization of A, C, E, and F, Aeschynomene indica; and $\mathbf{B}$, D, and $\mathbf{G}$, A. afraspera inoculated with ORS285$\triangle \operatorname{nodB}$ and ORS285, respectively. A and B, Root systems observed with a fluorescent stereomicroscope equipped with a green fluorescent protein (GFP) filter. Insets in A and B indicate fluorescence and bright-field micrographs showing the axillary root hairs in A. indica and A. afraspera, respectively. Bar, $250 \mu \mathrm{m}$. C and D, Confocal microscopy images showing the bacterial colonization at the emergence of lateral roots in $A$. indica and $A$. afraspera, respectively (2 days postinoculation [dpi]). C, Stack of 70 images taken at $0.34-\mu \mathrm{m}$ increments and $\mathbf{D}$, stack of 30 images taken at $1.16-\mu \mathrm{m}$ increments. Bar, $50 \mu \mathrm{m}$. E through $\mathbf{G}$, Scanning electron microscopy micrographs showing the surface colonization of the axillary root hairs of $\mathbf{E}$ and $\mathbf{F}$, A. indica and $\mathbf{G}$, A. afraspera (3 dpi). Bar, $5 \mu \mathrm{m}$. 
hairs were short and swollen and did not curl in the presence of the bacteria. Quantification of bacterial colonization indicated that the cell density reached $3.8 \times 10^{7}$ bacteria per gram of root tissue only $6 \mathrm{~h}$ after inoculation (Supplementary Fig. S2).
In contrast to other epidermal cells, the outer layer of axillary hairs consisted of a mucilage which formed a thick cap where bacteria were polarly attached (Figs. 2E and 3B). This mucilage material was also present in noninfected plants, indicating that
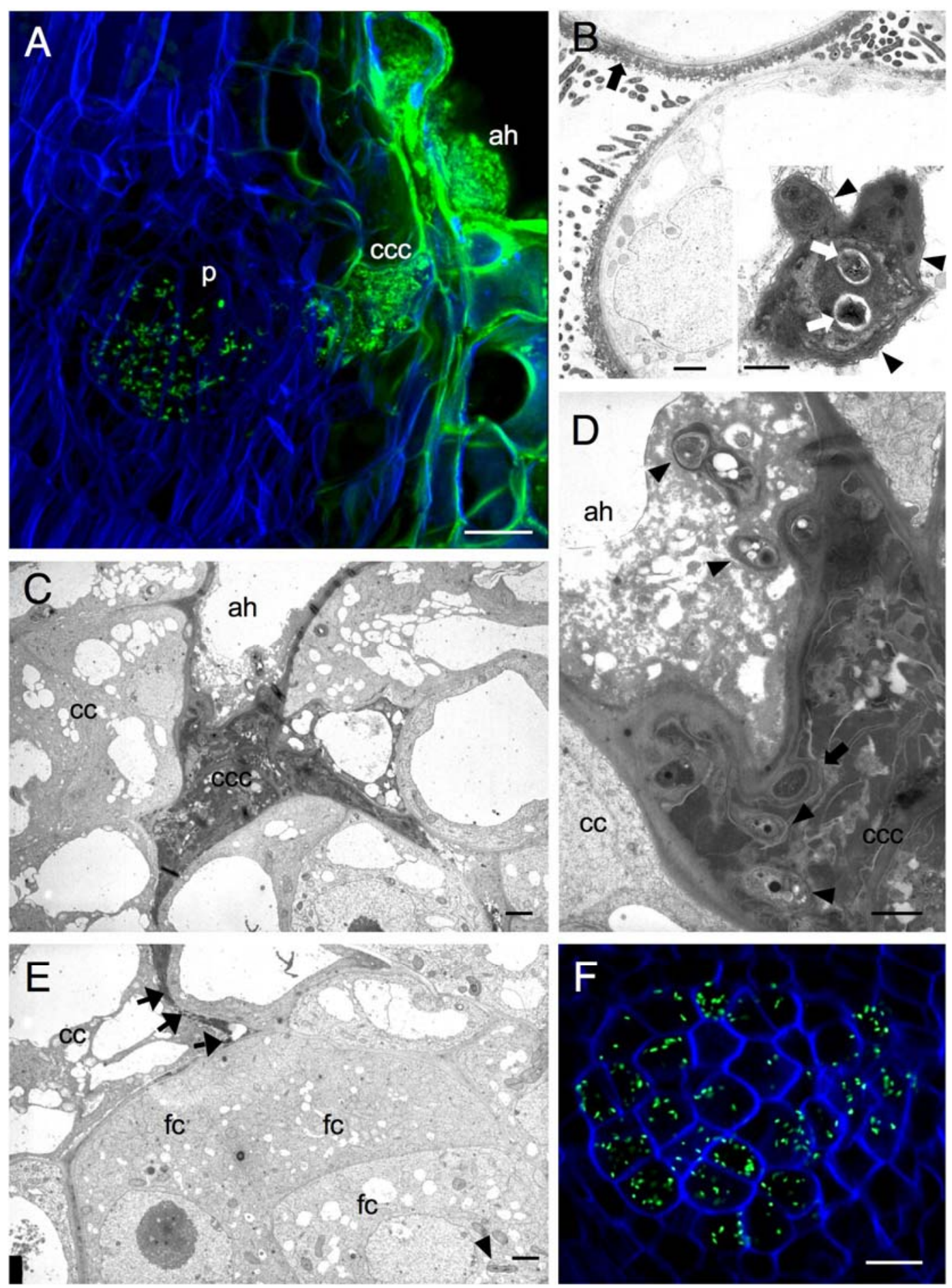

Fig. 3. Infection and nodule initiation on Aeschynomene indica ( 2 to 3 days postinoculation) by ORS285 $\Delta$ nodB. A, General overview of the progression of the bacteria inside the lateral root using confocal microscopy (stack of 30 images taken at $0.75-\mu \mathrm{m}$ increments). Bar, $20 \mu \mathrm{m}$. B, Transmission electron microscopy (TEM) micrograph showing the bacterial colonization of the axillary root hairs. Note the presence of a thick mucilage (black arrow) in the outer layer of axillary root hairs. Bar, $2 \mu \mathrm{m}$. Inset: internalization of several bacteria in an axillary root hair. Note that the bacteria (white arrows) are enclosed in a plasmalemma pocket (black arrowheads) and are surrounded by fibrillar material that surely originated from plant cell wall. Bar, $0.5 \mu \mathrm{m}$. C, TEM micrograph showing the intracellular infection of an axillary hair and underlying cortical cells. Note that the infected cortical cells are collapsed and that the cytoplasm is electron dense. Bar, $2 \mu \mathrm{m}$. D, Higher magnification of $\mathrm{C}$ showing the invagination of the host cell wall (arrow) and the internalization of the bacteria (arrowhead). Bar, $1 \mu \mathrm{m}$. E, Field adjacent to $\mathrm{C}$ showing the ultrastructure of the primordium founder cells. Note the presence of a bacterium (arrowhead) in one of the daughter cells. Note also that the young primordium is in direct contact with intercellular strand-like structures (arrows) originated from the collapsed cells primarily infected. Bar, $2 \mu \mathrm{m}$. F, Confocal microscopic image showing a young nodule primordium (stack of 30 images taken at $0.75-\mu \mathrm{m}$ increments). Bar, $20 \mu \mathrm{m}$; ah, axillary root hairs; p, primordium; ccc, collapsed cortical cells; fc, founder cell of the nodule primordium. 
its formation was not induced by the bacteria but constitutive (data not shown). Furthermore, the attachment of the bacteria to this mucilage appeared to be non-strain specific because inoculation with non-nodulating bacteria (Sinorhizobium meliloti or Rhodopseudomonas palustris) also led to a massive bacterial colonization of the axillary root hairs (data not shown).
In $A$. afraspera, the bacterial colonization density was $2.5 \times$ $10^{6} \mathrm{~g}^{-1}$ after $6 \mathrm{~h}$ (i.e., more than 10 -fold less than measured for A. indica) and this ratio was maintained during the first days of the infection. The bacteria were seen sparsely distributed all over the root surface (Fig. 2B, D, and G). In contrast to $A$. indica, axillary hairs were loose and displayed a smooth surface
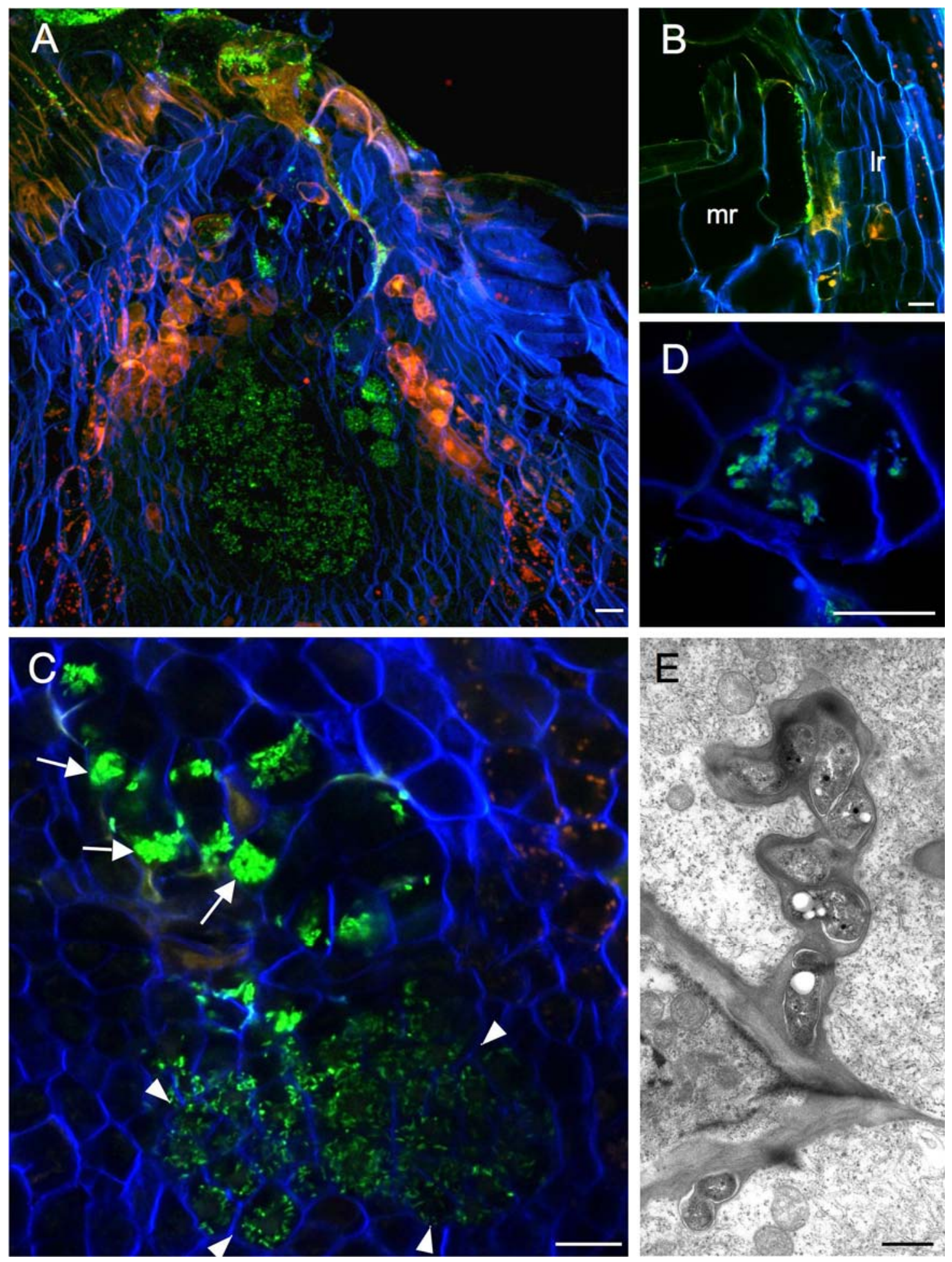

Fig. 4. Infection and nodule initiation in Aeschynomene afraspera ( 2 to 3 days postinoculation) by ORS285. A through D, Confocal microscopic images illustrating the invasion process. Bar, $20 \mu \mathrm{m}$. A, General overview of the progression of the bacteria inside the lateral root (stack of 30 images taken at 1.15 $\mu \mathrm{m}$ increments). B, Entry gate of the bacteria at the emergence site of a lateral root. C, Progression of the bacteria in the root cortex. Note that the bacteria appeared densely packed together in the outer layer cortical cells (arrows) whereas they appeared homogenously dispersed in the primordium cells (arrowheads). D, Higher magnification of the structure in which the bacteria were embedded. E, Transmission electron microscopy observation showing the ultrastructure of an intracellular intrusion enclosing several bacteria. Bar, $1 \mu \mathrm{m} ; \mathrm{mr}$, main root; lr, lateral root. 
(Fig. 2D and G). Some of them were strongly distorted but this was not due to bacteria because these deformations were also observed for noninoculated plants (Fig. 2B).

Between 2 and 3 dpi in $A$. indica, we observed that the bacteria formed a uniform layer at the surface of the axillary root hairs and penetrated deeper by colonizing all the intercellular spaces available between hairs (Figs. 2C and 3B). From this intercellular proliferation zone, bacteria invaded some axillary hairs and subepidermal cortical cells (Fig. 3A). Transmission electron microscopy (TEM) showed that the bacteria penetrated in host cells through a local invagination of the cell wall that enclosed bacteria (Fig. 3C and D). This led to an internalization of the bacteria in a plasmalemma pocket containing cell wall material (Fig. 3B). The first infected cortical cells showed significant signs of degeneration: i) a loss of the morphological integrity, the cells being compressed by neighboring cortical cells, and ii) a highly disorganized cytoplasm displaying amorphous electron-dense material where organelles were not
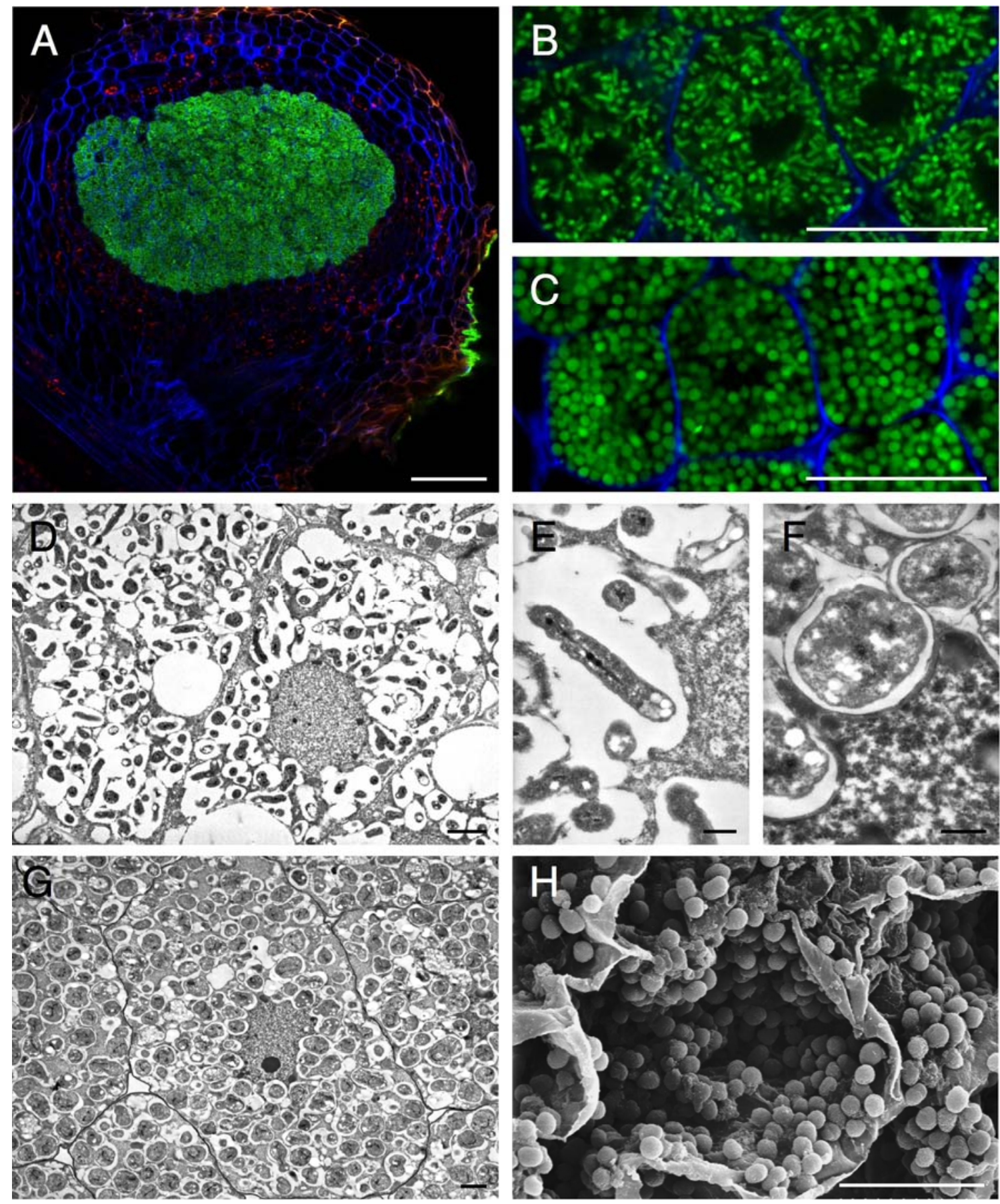

Fig. 5. Stages of nodule development in Aeschynomene indica elicited by ORS285 $\Delta$ nodB. A, Confocal microscopic image (CMI) showing a cross-section of a young nodule ( 6 days postinoculation [dpi]). Note that the primordium contains only infected cells. Bar, $100 \mu \mathrm{m}$. B and $\mathbf{C}$, CMIs showing the conformational change of bacteria that occurred between B, 4 and $\mathbf{C}, 5$ dpi. Bar, $20 \mu \mathrm{m}$. D, Transmission electron microscopy (TEM) showing an infected cell in division (4 dpi). Note that symbiosomes contain several rod-shaped bacteria. Bar, $2 \mu \mathrm{m}$. E, Higher magnification of bacteria (4 dpi). Note the presence of a condensed central fibrillar nucleoid and poly- $\beta$-hydroxybutyrate granules (light areas). Bar, $500 \mathrm{~nm}$. F, Higher magnification of bacteria (13 dpi). Bar, $500 \mathrm{~nm}$. G, TEM showing an infected cell at $13 \mathrm{dpi}$. Note the amoeboid morphology of the nucleus and individual bacteria in symbiosomes. Bar, $2 \mu \mathrm{m}$. $\mathbf{H}, \mathrm{Scanning}$ electron microscopy micrograph showing bacteroid-containing cells (13 dpi). Bar, $10 \mu \mathrm{m}$. 
distinguishable (Fig. 3C and D). Other cortical cells in direct contact with these collapsed cells were also infected by a process that remains to be disclosed. In contrast to the infected cells of the upper layer, these last cells kept their integrity in response to the infection and underwent successive and rapid mitosis, giving rise to the nodule primordium that was clearly distinguishable at $3 \mathrm{dpi}$ (Fig. 3A, E, and F).
As for A. indica, in A. afraspera the mitotic reactivation of cortical cells also was concomitant to their infection. However, the site of nodule initiation was located deeper in the root cortex (Fig. 4A). The bacteria first entered the plant at sites of lateral root emergences, at the point of contact between an axillary root hair and an epidermal cell of the primary root (Fig. 4B). The bacteria then spread deeper intercellularly over three or four cell
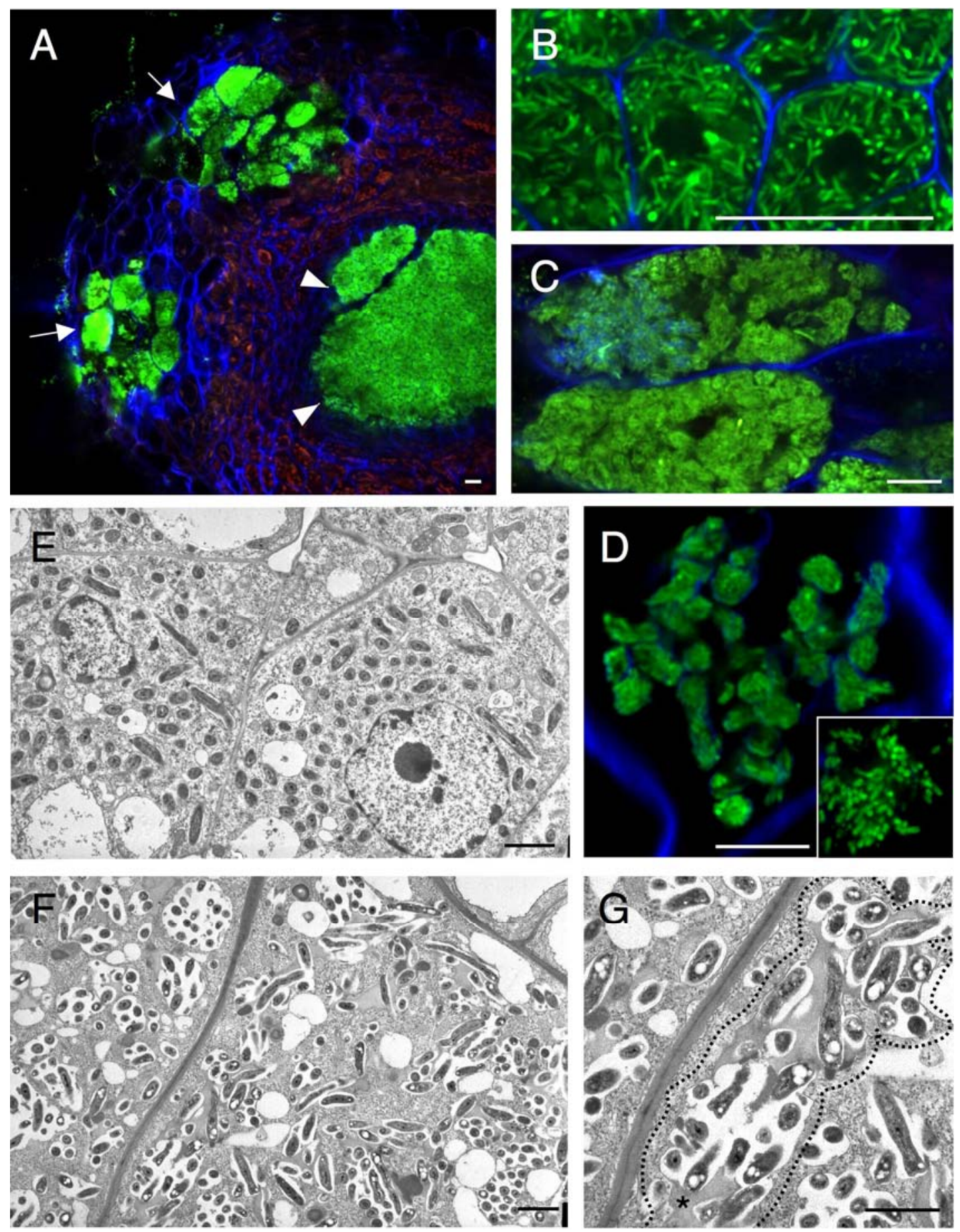

Fig. 6. Aeschynomene afraspera mature nodule (7 days postinoculation [dpi]) elicited by ORS285. A, Confocal microscopic image (CMI) showing a cross-section of a young nodule $(7 \mathrm{dpi})$. Note the presence of two infected zones: the central tissue (arrowheads) and the outgrowth on the top of the nodule (arrows). Bar, $20 \mu \mathrm{m}$. B and $\mathbf{C}$, Comparison of the host cells in the two infected zones: $\mathbf{B}$, the primordium cells and $\mathbf{C}$, the giant cells of the outgrowth. Bar, $20 \mu \mathrm{m}$. D, Higher magnification of C showing that bacteria are enclosed in large tubular structures arranged in convolutions. Bar, $10 \mu \mathrm{m}$. Inset: morphological aspect of the bacteria in the tubular structures. Note that bacteria are not elongated in comparison to the ones in the primordium cells shown in B at the same scale. $\mathbf{E}$ and $\mathbf{F}$, Comparison of the ultrastructure (transmission electron microscopy) of the host cells in the two infected zones: $\mathbf{E}$, the primordium cells and $\mathbf{F}$, the giant cells of the outgrowth. Bar, $2 \mu \mathrm{m}$. G, Higher magnification of F showing the detail of the tubular structures enclosing bacteria. The dashed line indicates the delimitation of one of this structure. Note the presence of remains of wall-like material (asterisks). Bar, $1 \mu \mathrm{m}$. 
layers in the root cortex and infected some cortical cells during their progression (Fig. 4A and C). Confocal observations showed that, in the infected cells of the outer cortical layers, the bacteria were densely packed together and the use of calcofluor dye indicated that they were embedded within a plant-wallderived material (Fig. 4C and D). TEM observations showed that the rhizobia entered the host cell by invagination of the cell wall but, contrary to what was observed in A. indica, these intracellular intrusions often penetrated deeply in the cell and enclosed several bacteria (Fig. 4E). During the progression in the root cortex, defense-like responses such as collapse of infected cells and extensive formation of wall-like material by the host cell occasionally were observed (Supplementary Fig. S3). Finally, when bacteria reached a deeper zone in the cortex, the invaded cortical cells divided rapidly to form the primordium (Fig. 4A and C). In contrast to the cells of the upper layers, the bacteria in the primordium were uniformly dispersed in individual symbiosome with no apparent cell wall material (Fig. 4C).

We also examined the infection of $A$. afraspera inoculated with ORS285 $\operatorname{nodB}$. Colonization of the root surface and,
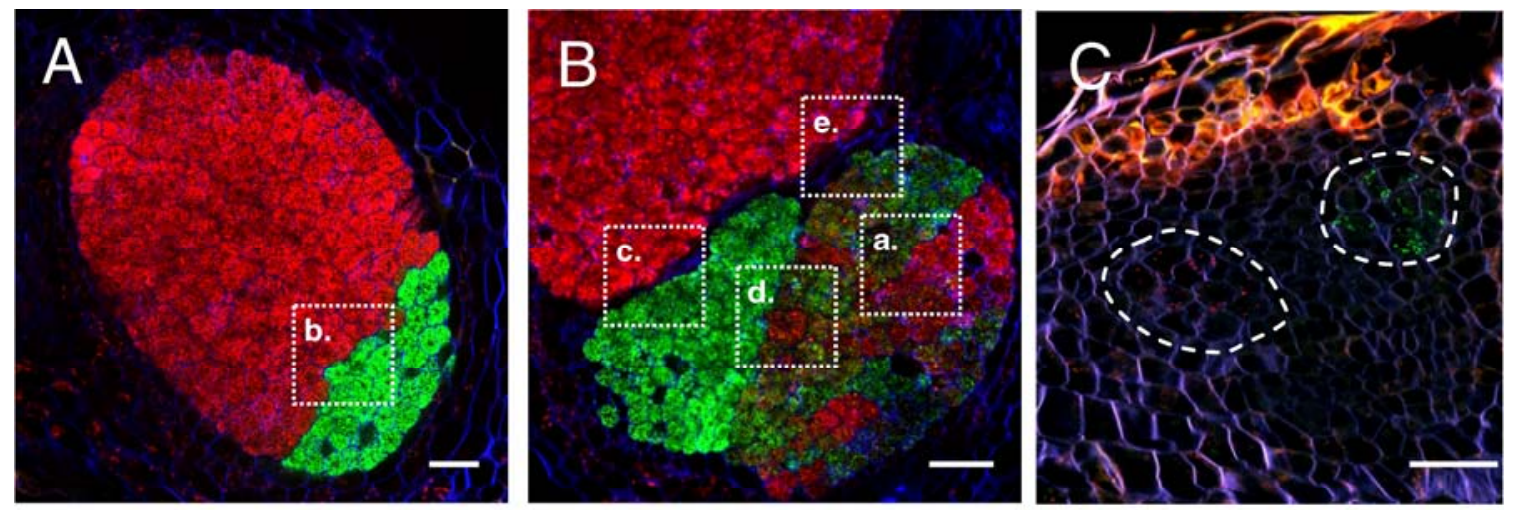

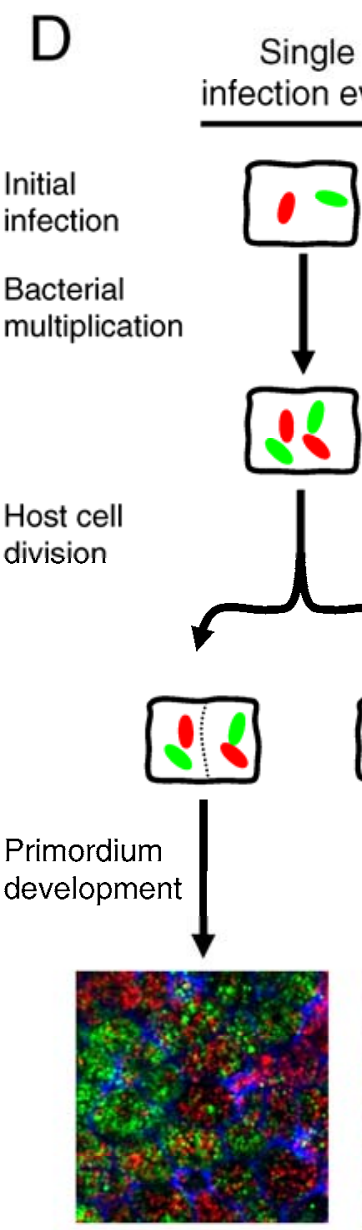

a
Single event
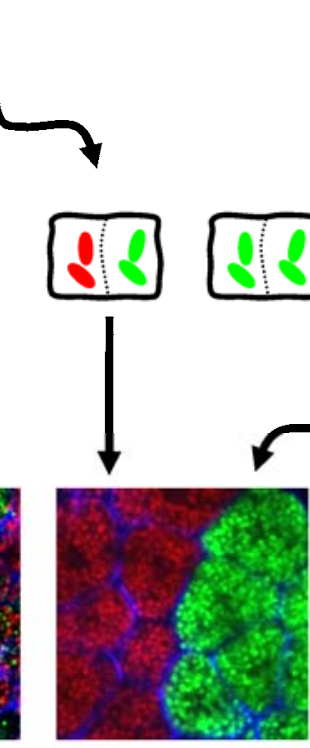

b

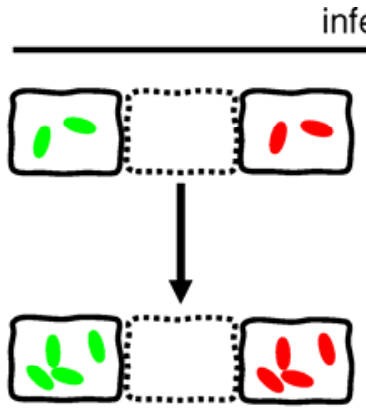

Multiple infection events
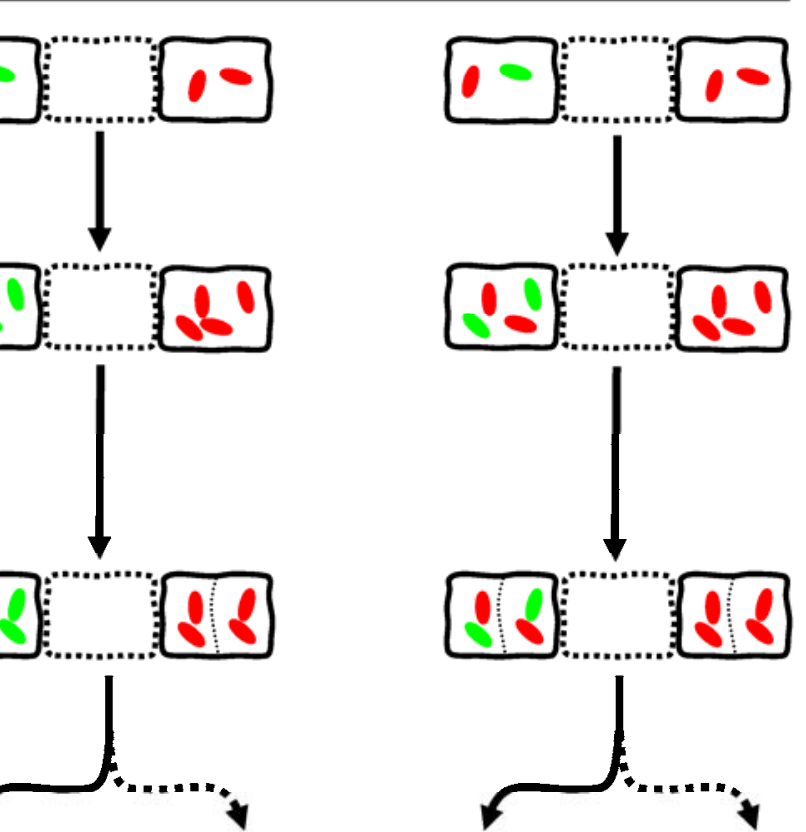

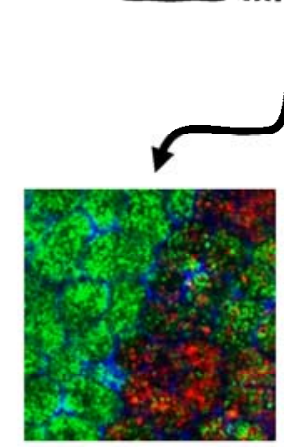

d

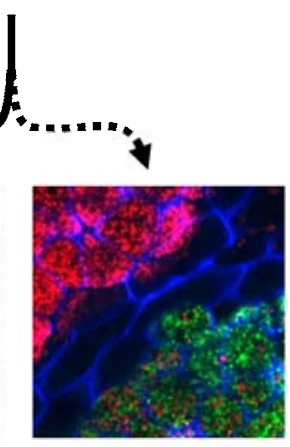

e

Fig. 7. Aeschynomene indica nodules infected with red and green fluorescent bacteria (ORS285 $\Delta$ nodB-green fluorescent protein (GFP) or -mCherry tagged strains. A and $\mathbf{B}$, Cross-section of nodules (5 days postinoculation [dpi]) showing a sectored distribution of red and green bacteria. Bar, $50 \mu \mathrm{m}$. Dashed squares (a through e) correspond to the possible scenarios of infection described in D. C, Cross-section of a young nodule ( 3 dpi) showing the initiation of two primordia populated by different type of bacteria. Bar, $50 \mu \mathrm{m}$. D, Five possible scenarios (a through e) for distributing a mixed population of bacteria in a single nodule. When multiple founder cortical cells are infected, they could be contiguous or separated by noninvaded interstitial cells (dashed-line). 
occasionally, a proliferation in the wound sites was observed. However, no further spread of the bacteria was seen in the root tissue. This confirms that NF were required to initiate the first infection steps in A. afraspera. In the same way, we examined the infection of $A$. indica using the NF-producing strain ORS285. The kinetics of nodulation and the pattern of infection analyzed by confocal microscopy was similar to that described with the ORS285 $\Delta$ nodB strain, indicating that, if NF were synthesized during the interaction, they didn't play any symbiotic roles.

\section{Nodule development.}

Mature A. indica and A. afraspera nodules displayed the classical histological organization of aeschynomenoid nodules (i.e., a large central zone of infected tissue surrounded by an uninfected nodule cortex comprising vascular bundles) (Fig. 5A) (Lavin et al. 2001). In both cases, the vascular bundles were connected with the vasculature of the primary root whereas the nodules were systematically attached to the lateral root.

Young A. indica nodules (4 days old) only contained rodshaped bacteria similar to their free-living form (Fig. 5B). Ultrastructurally, infected cells exhibited large symbiosomes, each containing several bacteria an ample symbiosome space (Fig. 5D and E). The symbiosome membrane, which probably originated from the plasma membrane, exhibited an irregular shape. The bacteria displayed a dense fibrillar nuclear material and contained electron transparent areas which were most probably poly- $\beta$-hydroxybutyrate granules (Fig. 5E). After less than $24 \mathrm{~h}$ (from 4 to $5 \mathrm{dpi}$ ), we observed that bacteria within the nodule became perfectly spherical and of uniform size ( $\varnothing 1.75 \pm 0.25 \mu \mathrm{m}$ ) (Fig. $5 \mathrm{C}$ and F to H). Such drastic conformational change has also been described in Arachis hypogea (Staphorst and Strijdom 1972). Concomitantly with this differentiation step, nitrogenase activity was detectable. TEM analysis of mature nodules (13 days old) showed only one spherical bacteroid per symbiosome, and very little space between the bacteroid and peribacteroid membrane was observed, which is in contrast to what was observed for younger symbiosomes (Fig. 5F and G). The extensive filling of host cells by bacteria resulted in an amoeboid shape of the nucleus (Fig. 5F and G).

Bacteroid differentiation was completely different in Aeschynomene afraspera. The bacteria remained rod shaped but their length increased with the age of the nodule, to reach approximately 5 to $10 \mu \mathrm{m}$ in 3-week-old nodules (Fig. 6B). Nodule organogenesis is also different in A. afraspera because we observed the development of an outgrowth at the top of nodules concomitantly with the primordium expansion (Figs. 1F and 6A). This tissue, probably derived from outer cortical cells colonization, was formed by a few giant cells filled with bacteria enclosed in a network of large tubular structures arranged in convolutions (Fig. 6C and D). TEM observations showed that these structures were delimited from host cell cytoplasm by a cytoplasmic membrane and contained remains of wall-like material (Fig. 6F and $\mathrm{G}$ ). Apart from the fact that the bacteria were enclosed in distinct structures in cells of the primordium or in cells of the outgrowth, they also displayed different morphological traits. Whereas the bacteria elongated in the central tissue (Fig. $6 \mathrm{~B})$, the size of the bacteria in the outgrowth remained similar to their free-living form, suggesting that differentiation into bacteroids did not occur (Fig. 6D).

\section{Multiple infections.}

To get more insights into the infection and invasion processes, we inoculated both Aeschynomene spp. with mixtures of bacteria tagged with GFP or mCherry. A. indica and $A$. afraspera plants were inoculated with derivatives of ORS285 $\triangle$ nodB and ORS285 strain, respectively. In both cases, plants harbored a majority of nodules (approximately 90\%) infected exclusively by red or green bacteria, suggesting that the bacterial population inside a single nodule originated from a limited number of bacteria. Confocal microscopy analyses of the nodules populated by both red and green bacteria were performed to examine the spatial distribution of the distinct subpopulations of bacteria, and similar observations were obtained for both plants. We observed that a single nodule could be divided in distinct sectors populated exclusively by green or red bacteria or by a mixture of green and red bacteria (Fig. 7A and B). These different sectors could be separated or not by files of uninvaded cells. Furthermore, a section of very young nodules (Fig. 7C) revealed that two independent infections close to one another could simultaneously occur. Altogether, these observations indicated that nodule organogenesis could result from a coordinated development of several primordia originating from independent infection events and that several bacteria could be delivered in the founder cortical cells (Fig. 7D). When sectors were ad-
A

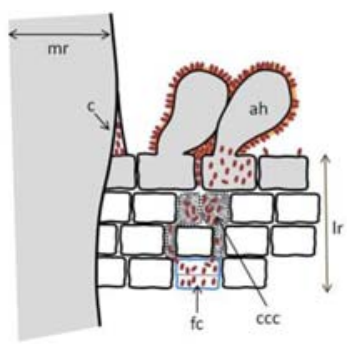

B

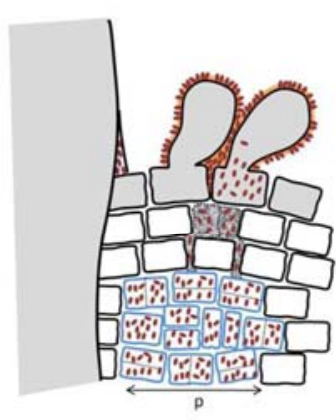

C

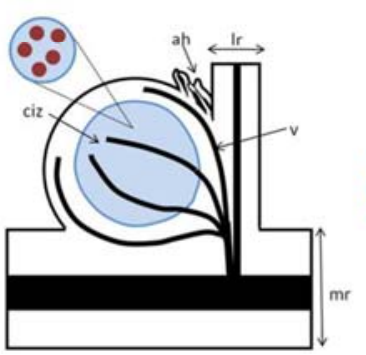

D

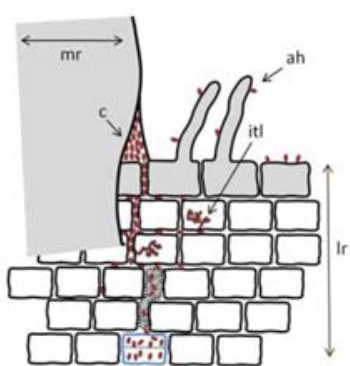

E
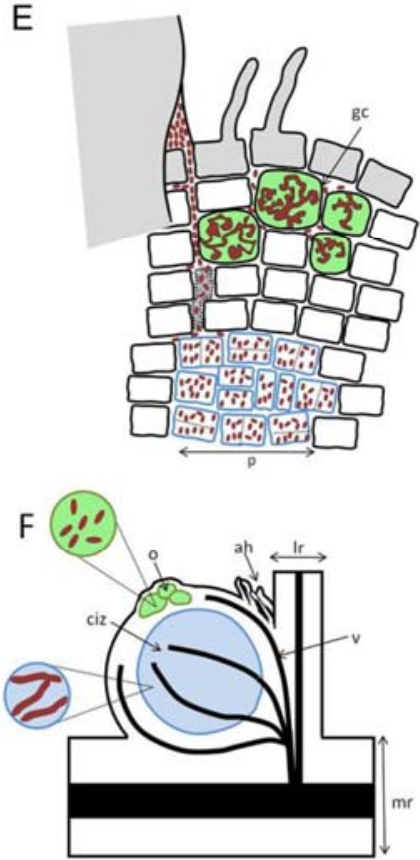

Fig. 8. Schematic comparison of the Nod factor (NF)-independent and NF-dependent nodulation processes in A through C, Aeschynomene indica and $\mathbf{D}$ through $\mathbf{F}$, A. afraspera, respectively. Nodulation stages were $\mathbf{A}$ and $\mathbf{D}, 1$ to 2 days postinoculation (dpi); $\mathbf{B}$ and $\mathbf{E}, 3$ to $4 \mathrm{dpi}$; and $\mathbf{C}$ and $\mathbf{F}$, mature nodules. Note that the drawing dimensions are adapted and not proportional to the actual dimensions. Abbreviations: mr, main root; 1r, lateral root; c, crack; ah, axillary root hairs; ccc, collapsed cortical cells; p, primordium; fc, founder cell of the nodular primordium; gc, giant cell; o, outgrowth; itl, infection-thread like structures, v, vascularization; ciz, central infected zone. Epidermal cells (gray) and cortical cells (white). 
jacent, two scenarios are possible: i) two contiguous cortical founder cells are concomitantly infected or ii) a single cortical founder is infected by a mixed population of bacteria that segregated between the daughter cells (Fig. 7D).

\section{DISCUSSION}

Here, we compare the NF-dependent and NF-independent strategy that is used by the same photosynthetic Bradyrhizobium strain, ORS285, to nodulate two Aeschynomene spp., A. afraspera or $A$. indica. We observed that the symbiotic efficiency in terms of nodulation kinetics, nodule number, and strain virulence was very similar between the two species, clearly indicating that the absence of NF does not limit the establishment of the symbiosis. Although the establishment of the symbiotic organ in both Aeschynomene spp. displayed some common characteristics with that described in Stylosanthes spp. and Arachis hypogea, major differences were also observed in the mechanism of plant invasion, nodule organogenesis, and bacteroid differentiation (Fig. 8).

\section{Entry of bacteria occurs between epidermal cells in both Aeschynomene indica and A. afraspera.}

During both invasion ways, bacteria entered at the contact between two epidermal cells: two axillary root hairs in Aeschynomene indica and between an axillary hair and an epidermal cell of the primary root in A. afraspera (Fig. 8). The first prominent difference was the number of bacteria that were attached to the axillary hairs. Many more bacteria could be seen on $A$. indica axillary root hairs, which were surrounded by a thick mucilage layer, compared with those of $A$. afraspera. As established in pea and cowpea (Knee et al. 2001), this mucilage is likely of polysaccharidic nature. It could play a role in chemoattraction and proliferation of bacteria because, in other legumes, it was shown to be utilized as a carbon source by rhizobia (Knee et al 2001). Because bradyrhizobia entered roots at a contact zone between axillary hairs, this root hair colonization might be important for nodulation. The intercellular infection resembled the process that has been described in Arachis hypogea, where bacteria penetrate between an axillary root hair and an adjoining epidermal cell (Chandler et al. 1982). However, whereas axillary root hairs were shown to be absolutely required in A. hypogea (Nambiar et al. 1983), they might still be dispensable for both Aeschynomene spp. Indeed, inoculation of young plantlets (stage before lateral root emergence) inhibited axillary root hair formation but this did not prevent nodulation (Giraud et al. 2007). In addition, both Aeschynomene spp. can form nodules on the stem that is devoid of hairs. In these last cases, bacteria invaded the root cortex through natural wounds caused by the splitting of epidermis at the emergence of lateral roots.

\section{A simple infection process involving neither}

\section{transcellular IT nor distant induction of a primordium.}

In both species, bacteria enter the host cell through an uptake mechanism that starts with invagination of the plant cell wall and membrane. In Aeschynomene afraspera, these invaginations penetrate deeper into the cells and include several bacteria. These invaginations never extend beyond the boundaries of the host cell and, therefore, cannot be considered as transcellular threads that generally promote cell-to-cell spread of bacteria in temperate legumes. These structures rather resemble the "infection pegs" first described in Phaseolus spp. (Rae et al. 1992).

Cell invasion appeared to have a deleterious effect on some cortical cells of the outer layers. Indeed, in both Aeschynomene spp., some collapsed cells were observed that were com- pressed by neighboring cells. This response resembles the elicitation of defense mechanisms by pathogenic bacteria. Most of intercellular infection strategies described thus far during rhizobial symbiosis seem to come with cell death, although the intensity of it differs between different symbioses. Cell death was reported to be part of Stylosanthes spp. infection and is the underlying cause of infection pocket formation on Sesbania rostrata (Capoen et al. 2010; Chandler et al. 1982; D’Haeze et al. 2003). Plant cell death might support colonization of deeper cortical cell layers because the collapsed cells are squeezed to such an extent that they form strand-like structures that progress in the deeper intercellular spaces. In contrast to what is observed in the outer cell layers, the host and bacteria appear to be in complete harmony in the deeper layers of the cortex because the infection promotes the cell cycle reactivation of the founder cells, leading to the establishment of the proper symbiotic tissue.

The multiple infection experiments showed that several bacteria could be delivered in a single founder cortical cell and that nodule organogenesis could result from successive division of several infected founder cells. However, considering that only one type of bacteria was generally observed, a high proportion of nodules probably house a clonal population and originate from the successive divisions of only one infected founder cell.

The observation that primordium formation is only activated after the first bacteria are taken up by the plant cells is a typical trait of Aeschynomene spp. whereas, in the greatest majority of legume species, cell division is initiated at a distance from the invading bacteria. This event is independent of the absence of NF because it was also observed during $A$. afraspera infection. In contrast to what was observed here during root nodulation, Alazard and Duhoux (1990) suggested that, in A. afraspera, NF synthesis by the bacteria induced a meristematic zone at some distance from the first infected cells during stem nodule development. Confocal observations revealed that the number of bacteria inside host cells was very low during the initial step of primordium division (less than 10 bacteria per cell) and, hence, might be overlooked by regular microscopy. It would be interesting to reexamine stem nodule development in A. afraspera using a confocal approach to determine whether the mechanism of root and stem infection really differs.

\section{Two distinct infected tissues in mature $A$. afraspera nodules.}

A unique feature of $A$. afraspera nodules is the presence of two distinct infected tissues: i) the central core exclusively filled with infected cells that results from successive divisions of the primordium founder cells and ii) a superficial tissue constituted by a few giant infected cells. Whereas the bacteria in the central tissue are differentiated and are enclosed singly in symbiosomes, they are undifferentiated and enclosed collectively in large tubular structures in the cells of the outgrowth. The distal localization of this last tissue suggests that it originates from the primarily infected outer cortical cells that did not collapse. In these cells, the initial intracellular intrusions have continued to grow massively inside the cells without releasing bacteria into the host cytoplasm. The presence of numerous organelles, including ribosomes and amyloplasts, reflects their good health. It seems that, in contrast to the deeper cortical cells that will make up the nodule central tissue, these cells did not undergo mitotic reactivation. The intracellular intrusions, in which the bacteria remain enclosed, is reminiscent of permanent IT observed in primitive legumes of the Caesalpinioideae spp. and in the non-legume Parasponia spp. (de Faria et al. 1987; Lancelle 
and Torrey 1984). It has been shown that nitrogen fixation occurs in these structures but this is probably not the case for A. afraspera because the bacteria remain undifferentiated in contrast to those within the central tissue. This raises the question of whether a truly symbiotic relationship does exist in this tissue. Because rhizobia are known to lose their viability following the differentiation step (Gresshoff et al. 1977; McRae et al. 1989), this infected tissue might constitute a kind of reservoir that retains a population of viable bacteria able to reinfect the plant after nodule senescence.

\section{Bacteria have different bacteroid differentiation fates in the two Aeschynomene spp.}

It is well accepted that the bacteroid differentiation step is controlled by the legume host rather than by the bacterial genotype (Oke and Long 1999). Our observations further emphasize this and show that bacterial fate might be different in two closely related species. Whereas bacteroids elongated in A. afraspera, they changed to a spherical form in A. indica. Considering that the nitrogen-fixing activity per unit nodule was twofold higher for $A$. afraspera compared with $A$. indica, we can ask whether the elongated form is more efficient in fixing nitrogen. This question has been examined in the case of peanut and cowpea legumes, during which the same bacterium led to spherical or elongated bacteroids, respectively (Sen and Weaver 1984). In contrast to what is observed in Aeschynomene spp., the higher nitrogenase fixation was found in nodules harboring the spherical bacteroids (i.e., peanut nodules). However, measurement of nitrogenase activity on isolated bacteroids revealed that cowpea bacteroids were more effective, indicating that the bacteroid morphology does not determine efficiency. Instead, other factors such as the size and the anatomy of nodules, the number of bacteroids, and, surely, the control of the bacterial feeding by the plant are probably more critical.

\section{The NF-independent process: an ancestral symbiotic mechanism?}

NF are known to play key roles during all the steps of the infection process by triggering root hair curling, IT formation, and the induction of a nodule primordium. None of these NFrelated responses were observed in A. indica but, instead, a more primitive form of colonization was seen, involving cell collapse and direct entry in outer cortical cells, after which they initiated division (Fig. 8). It is assumed in the history of legume evolution that the dalbergioid clade has separated before the millettioid and galegoid clades to which the classical model legumes belong (Lavin et al. 2005). It could be possible that the requirement for NF is less predominant or even dispensable in this more ancient lineage and that NF signaling evolved to allow intracellular infection via root hairs. In addition, NF signaling would have enabled the separation of bacterial infection and cell division. Interestingly, in the model plant Lotus japonicus, it has been reported recently that double mutants affected in some determinants of the NF signaling pathway were occasionally able to form functional nodules when the plants were inoculated with a compatible rhizobia unable to produce NF (Madsen et al. 2010). In this last case, the bacteria infected the plant by a process very similar to that described in A. indica. It has been hypothesized that intercellular infection in the absence of IT and NF may constitute the ground state of rhizobial infection whereas the root hair infection mode would be the most highly evolved state (Madsen et al. 2010). Therefore, A. indica nodule development could be considered to be a living testimony of the ancient symbiosis whereas $A$. afraspera symbiosis might illustrate the next evolutionary step involving NF signaling. Further studies on the Aeschynomene spp.-photosynthetic Bradyrhizobium interac- tion should shed new light on the evolution of Rhizobium spp.legume symbiosis but might also uncover the basic underlying processes of nodulation that might be used to develop new strategies to create artificial plant-bacterium symbioses.

\section{MATERIALS AND METHODS}

\section{Bacterial strains, plasmids, and growth conditions.}

Bradyrhizobium sp. strains ORS285 and ORS285 $\Delta$ nodB (Giraud et al. 2007) were grown at $37^{\circ} \mathrm{C}$ in modified YM (YMm) medium (Giraud et al. 2000). When required, the media was supplemented with kanamycin $\left(50 \mu \mathrm{g} \mathrm{ml} \mathrm{m}^{-1}\right)$. ORS285 and ORS285 $\Delta$ nodB strains were tagged with GFP or mCherry using the pMG103-nptII-GFP and pMG103-nptII$m$ Cherry plasmids, respectively (Bonaldi et al. 2010a).

\section{Plant growth and inoculation.}

$A$. indica or $A$. afraspera seed were surface sterilized with concentrated (96\%) sulfuric acid for 30 and $45 \mathrm{~min}$, respectively. Subsequently, the seed were abundantly rinsed with sterile water and incubated overnight in sterile water. The seed were transferred onto sterile $0.8 \%$ water agar plates and germinated upside down overnight at $37^{\circ} \mathrm{C}$ in the dark. One day-old seedlings were aseptically transferred to test tubes filled with $55 \mathrm{ml}$ of BNM medium (Ehrhardt et al. 1992). To allow passage of the radicle, a small hole in the aluminum foil cap was made using a sterile toothpick. Seedlings were grown in a small greenhouse placed in a $28^{\circ} \mathrm{C}$ growth chamber with a 16 -h light regime and $70 \%$ humidity. Five days after transfer, each seedling was inoculated with $1 \mathrm{ml}$ of a 5-day-old bacterial culture after washing and adjusting the optical density at $600 \mathrm{~nm}$ to 1 .

\section{Plant tests.}

For nodulation and nitrogen fixation kinetics at different times postinoculation $(3,5,6,7,10,14$, and 21 days), five plants were taken and analyzed for the number of nodules and nitrogenase activity as previously described (Bonaldi et al. 2010b).

To analyze root colonization at different times postinoculation $(0,6,24,48,72,96$, and $120 \mathrm{~h})$, the roots from three individual plants were gently rinsed with distilled water to remove loosely adhering bacteria. Rinsed roots were weighted and crushed in a mortar containing $5 \mathrm{ml}$ of sterile water, and serial dilutions were plated onto YMm-agar plates. Plates were incubated for 1 week at $28^{\circ} \mathrm{C}$ and the number of colonies was determined.

\section{Histochemical analysis and light microscopy.}

Roots and nodules samples were collected as early as $6 \mathrm{~h}$ after inoculation, daily from day 1 through 7 , and finally at 14 and $21 \mathrm{dpi}$. Microscopic observations were performed on 30to 40- $\mu$ m-thick vibratome (Leica VT1000S) sections from fresh roots and nodules samples using either a fluorescence stereomicroscope (Nikon AZ100; Champigny-sur-Marne, France) or a microscope (Olympus, Rungis, France).

\section{Confocal microscopy.}

For staining of the plant cell wall, sections were incubated in $10 \mathrm{mM}$ phosphate saline buffer (PBS) containing calcofluor white M2R (Sigma, Munich) to a final concentration of $0.01 \%$ (wt/vol) (Nagata and Takebe 1970). After washing with PBS, the sections were mounted on microscope slides in PBS containing glycerol at a final concentration of $50 \%$ ( $\mathrm{vol} / \mathrm{vol})$. Analyses were carried out using a confocal laser-scanning microscope (Carl Zeiss LSM 700; Jena, Germany). Calcofluor, GFP, and mCherry were excited at 405, 488, and $555 \mathrm{~nm}$, respectively. In the case of the 488-nm excitation, the emission 
signal was collected on two channels: channel 1 (490 to 520 $\mathrm{nm})$ was used to visualize the GFP emission and channel 2 (520 to $700 \mathrm{~nm}$ ) was used for visualization of the plant autofluorescence. This permitted us to visualize the autofluorescence of chloroplast that appeared in red, the yellow-orange fluorescence most probably corresponding to the accumulation of polyphenol compounds. Images were processed using the Carl Zeiss Confocal Software (Zen 2009).

\section{TEM.}

Samples were fixed in a $4 \%$ glutaraldehyde, $0.1 \mathrm{M}$ cacodylate buffer ( $\mathrm{pH} 7.2$ ), postfixed in $1 \%$ osmium tetroxyde, dehydrated using a series of acetone washes, and embedded in TAAB 812 epon resin. Ultrathin sections $(60 \mathrm{~nm})$ were mounted on collodion carbon-coated copper grids, contrasted using uranyl acetate and lead citrate, and examined at $80 \mathrm{kV}$ with a transmission electron microscope (Jeol 100CX II).

\section{Scanning electron microscopy.}

Samples were fixed with $2.5 \%$ glutaraldehyde in PBS buffer, $\mathrm{pH} 7.2$, for an hour at room temperature, followed by washing in PBS buffer. Fixed samples were dehydrated using a graded ethanol series (30 to $100 \%$ ), followed by $2 \mathrm{~min}$ in hexamethyldisilazane. Subsequently, the samples were sputter coated with an approximately 10-nm-thick gold film and then examined under a scanning electron microscope (Hitachi S4000; CRIC, Montpellier, France) using a lens detector with an acceleration voltage of $10 \mathrm{kV}$ at calibrated magnifications.

\section{ACKNOWLEDGMENTS}

This work was supported by grants from the French national research agency (ANR-NEWNOD-2006-BLAN-0095 and ANR-SESAM-2010BLAN-170801), the bilateral Franco-Belgium Egide program (18074NJ), and the "Ministère de l'Education Nationale, de l'Enseignement Supérieur et de la Recherche" (fellowship to K. Bonaldi). We thank E. Duhoux (IRD, France), A. Verméglio (CEA, Cadarache France), and B. Gourion (ISV, CNRS, Gif-sur-Yvette, France) for stimulating discussions; and C. Cazevieille and C. Sanchez for their technical assistance and interpretation of data concerning ultrastructural evaluation (Centre de Ressources en Imagerie Cellulaire, IURC, 641 Avenue du Doyen Gaston Giraud 34093 Montpellier, cedex 5, France).

\section{LITERATURE CITED}

Alazard, D., and Becker, M. 1987. Aeschynomene as green manure for rice. Plant Soil 101:141-143.

Alazard, D., and Duhoux, E. 1988. Diversity of stem nodulation sites in Aeschynomene spp. J. Plant Physiol. 132:123-125.

Alazard, D., and Duhoux, E. 1990. Development of stem nodules in a tropical forage legume, Aeschynomene afraspera. J. Exp. Bot. 41:11991206.

Arora, N. 1954. Morphological development of the root and stem nodules of Aeschynomene indica L. Phytomorphology 4:211-216.

Boivin, C., Ndoye, I., Molouba, F., de Lajudie, P., Dupuy, N., and Dreyfus, B. 1997. Stem nodulation in legumes: Diversity, mechanisms and unusual characters. Crit. Rev. Plant Sci. 16:1-30.

Bonaldi, K., Gherbi, H., Franche, C., Bastien, G., Fardoux, J., Barker, D. Giraud, E., and Cartieaux, F. 2010a. The Nod factor-independent symbiotic signaling pathway: Development of Agrobacterium rhizogenesmediated transformation for the legume Aeschynomene indica. Mol. Plant-Microbe Interact. 23:1537-1544.

Bonaldi, K., Gourion, B., Fardoux, J., Hannibal, L., Cartieaux, F., Boursot, M., Vallenet, D., Chaintreuil, C., Prin, Y., Nouwen, N., and Giraud, E. 2010b. Large-scale transposon mutagenesis of photosynthetic Bradyrhizobium sp. strain ORS278 reveals new genetic loci putatively important for nod-independent symbiosis with Aeschynomene indica. Mol. Plant-Microbe Interact. 23:760-770.

Boogerd, F. C., and van Rossum, D. 1997. Nodulation of groundnut by Bradyrhizobium: A simple infection process by crack entry. FEMS (Fed. Eur. Microbiol. Soc.) Microbiol. Rev. 21:5-27.

Capoen, W., Oldroyd, G., Goormachtig, S., and Holsters M. 2010. Sesbania rostrata: A case study of natural variation in legume nodulation.
New Phytol. 186:340-345.

Chaintreuil, C., Boivin, C., Dreyfus, B., and Giraud E. 2001. Characterization of the common nodulation genes of the photosynthetic Bradyrhizobium sp. ORS285 reveals the presence of a new insertion sequence upstream of nodA. FEMS (Fed. Eur. Microbiol. Soc.) Microbiol. Lett. 194:83-86.

Chandler, M. R. 1978. Some observations on infection of Arachis hypogaea L. by Rhizobium. J. Exp. Bot. 29:749-755.

Chandler, M. R., Date, R. A., and Roughley, R. J. 1982. Infection and rootnodule development in Stylosanthes species by Rhizobium. J. Exp. Bot. 33:47-57

de Faria, S. M., McInroy, S. G., and Sprent, J. I. 1987. The occurrence of infected cells, with persistent infection threads, in legume root nodules. Can. J. Bot. 65:553-558.

D’Haeze, W., De Rycke, R., Mathis, R., Goormachtig, S., Pagnotta, S., Verplancke, C., Capoen, W., and Holsters, M. 2003. Reactive oxygen species and ethylene play a positive role in lateral root base nodulation of a semiaquatic legume. Proc. Natl. Acad. Sci. U.S.A. 100:1178911794.

Eaglesham, A. R. J, Ellis, J. M., Evans, W. R., Fleischman, D. E., Hungria, M., and Hardy, R. W. F. 1990. The first photosynthetic N2 fixing rhizobium: Characteristics. Pages 805-811 in: Nitrogen Fixation: Achievements and Objectives. P. M. Greshoff, L. E. Roth, G. Stacey, and W. E. Newton, eds. Chapman and Hall, New York, London.

Ehrhardt, D. W., Atkinson, E. M., and Long, S. R. 1992. Depolarization of alfalfa root hair membrane potential by Rhizobium meliloti Nod factors. Science 256:998-1000.

Gage, D. J. 2004. Infection and invasion of roots by symbiotic, nitrogenfixing rhizobia during nodulation of temperate legumes. Microbiol. Mol. Biol. Rev. 268:280-300.

Gibson, K. E., Kobayashi, H., and Walker, G. C. 2008. Molecular determinants of a symbiotic chronic infection. Annu. Rev. Genet. 42:413-441.

Giraud, E., and Fleishman, D. 2004. Nitrogen-fixing symbiosis between photosynthetic bacteria and legumes. Photosynth. Res. 82:115-130.

Giraud, E., Hannibal, L., Fardoux, J., Verméglio, A., and Dreyfus, B. 2000. Effect of Bradyrhizobium photosynthesis on stem nodulation of Aeschynomene sensitiva. Proc. Natl. Acad. Sci. U.S.A. 97:14795-14800.

Giraud, E., Moulin, L., Vallenet, D., Barbe, V., Cytryn, E., Avarre, J. C., Jaubert, M., Simon, D., Cartieaux, F., Prin, Y., Bena, G., Hannibal, L. Fardoux, J., Kojadinovic, M., Vuillet, L., Lajus, A., Cruveiller, S., Rouy, Z., Mangenot, S., Segurens, B., Dossat, C., Franck, W. L., Chang, W. S., Saunders, E., Bruce, D., Richardson, P., Normand, P., Dreyfus, B., Pignol, D., Stacey, G., Emerich, D., Vermeglio, A., Medigue, C., and Sadowsky, M. 2007. Legumes symbioses: Absence of Nod genes in photosynthetic bradyrhizobia. Science 316:1307-1312.

Gresshoff, P. M., Skotnicki, M. L., Eadie, J. F., and Rolfe, B. G. 1977. Viability of Rhizobium trifolii bacteroids from clover root nodules. Plant Sci. Lett. 10:299-304.

Knee, E. M., Gong, F. C., Gao, M., Teplitski, M., Jones, A. R., and Foxworthy, A. 2001. Root mucilage from pea and its utilization by rhizosphere bacteria as a sole carbon source. Mol. Plant-Microbe Interact. 14:775-784.

Lancelle, S. A., and Torrey, J. G. 1984. Early development of Rhizobiuminduced root nodules of Parasponia rigida. II. Nodule morphogenesis and symbiotic development. Can. J. Bot. 63:25-35.

Lavin, M., Pennington, R. T., Klitgaard, B. B., Sprent, J. I., Cavalcante de Lima, H., and Gasson, P. E. 2001. The dalbergioid legumes (Fabaceae): Delimitation of a pantropical monophyletic clade. Am. J. Bot. 88:503553.

Lavin, M., Herendeen, P.S., and Wojciechowski, M.F. 2005. Evolutionary rates analysis of Leguminosae implicates a rapid diversification of lineages during the tertiary. Syst. Biol. 54:575-94.

Loureiro, M. F., James, E. K., Sprent, J. I., and Franco, A. A. 1995. Stem and root nodules on the tropical wetland legume, Aeschynomene fluminensis. New Phytol. 130:531-544.

Madsen, L. H., Tirichine, L., Jurkiewicz, A., Sullivan, J. T., Heckmann, A. B., Bek, A. S., Ronson, C. W., James, E. K., and Stougaard J. 2010. The molecular network governing nodule organogenesis and infection in the model legume Lotus japonicus. Nat. Commun. 1:10. Published online. doi: 10.1038/ncomms 1009 .

McRae, D. G., Miller, R. W., and Berndt, W. B. 1989. Viability of alfalfa nodule bacteroids isolated by density gradient centrifugation. Symbiosis 7:67-80.

Nagata, T., and Takebe, L. 1970. Cell wall regeneration and cell division in isolated tobacco mesophyll protoplasts. Planta 92:301-308.

Nambiar, P. T. C., Nigam, S. N., Dart, P. J., and Gibbons, R. W. 1983. Absence of root hairs in non-nodulating groundnuts, Arachis hypogaea L. J. Exp. Bot. 34:484-488.

Ndoye, I., de Billy, F., Vasse, J., Dreyfus, B., and Truchet, G. 1994. Root nodulation of Sesbania rostrata. J. Bacteriol. 176:1060-1068. 
Oke, V., and Long, S. R. 1999. Bacteroid formation in the Rhizobium-legume symbiosis. Curr. Opin. Microbiol. 2:641-646.

Rae, A. L., Bonfante-Fasolo, P., and Brewin, N. J. 1992. Structure and growth of infection threads in the legume symbiosis with Rhizobium leguminosarum. Plant J. 2:385-395.

Sen, D., and Weaver, R. W. 1984. A basis for different rates of N2-fixation by the same strains of Rhizobium in peanut and cowpea root nodules. Plant Sci. Lett. 34:239-246.

Sprent, J. I. 1989. Which steps are essential for the formation of functional legume nodules? New Phytol. 111:129-153.

Staphorst, J. L., and Strijdom, B. W. 1972. Some observations on the bac- teroids in nodules of Arachis sp. and isolation of rhizobia from these nodules. Phytophylactica 4:87-92.

Subba-Rao, N. S., Mateos, P. F., Baker, D., Pankrazt, H., Palma, J., Dazzo,

F. B., and Sprent, J. I. 1995. The unique root-nodule symbiosis between Rhizobium and the aquatic legume Neptunia natans (L.f.) Druce. Planta 196:311-320.

Vaughn, K. C., and Elmore, C. D. 1985. Ultrastructural characterization of nitrogen-fixing stem nodules on Aeschynomene indica. Cytobios 42:49-62.

Yatazawa, M., Yoshida, S., and Maeda, E. 1984. Fine structure of root nodules of. Aeschynomene indica. L. Soil Sci. Plant Nutr. 30:405-441. 